\title{
Melting properties of some structured lipids native to high stearic acid soybean oil
}

\author{
By G.R. List ${ }^{\star}$, R.O. Adlof, C.J. Carrierre and R.O. Dunn \\ Food and Industrial Oil Research, National Center for Agricultural Utilization, ARS, USDA, \\ 1815 N. University Street, Peoria, II 61604.
}

Ph. 309-681-6388. Fax 309-681-6340. E-mail: listGR@ncaur.usda.gov

\section{RESUMEN}

Propiedades de fusión de algunos lípidos estructurados procedentes del aceite de soja con alto contenido en ácido esteárico.

Se sintetizaron algunos lípidos estructurados procedentes del aceite de soja con alto contenido en ácido esteárico y sus propiedades físicas se determinaron por resonancia magnética nuclear pulsada (NMR), punto de goteo Mettler y calorimetría diferencial de barrido (DSC). Se sintetizaron 1,3 diestearo-2-oleina (SOS), 1,3 diestearo-2-linoleina (SLS) y 1,3 diestearo-2-linolenina (SInS) a partir de 1,3 diacilgliceroles y de los ácidos grasos adecuados puros. Las determinaciones de NMR pulsada en el rango de temperaturas $10-50^{\circ} \mathrm{C}$ mostraron que los triacilgliceroles simétricos (SUS: donde $S$ = esteárico, $U$ = oleico, linoleico o linolénico) funden a mayor temperatura y más bruscamente, todos presentan altos contenidos en sólidos a todas las temperaturas hasta los $33.3^{\circ} \mathrm{C}$, estando completamente fundidos a sólo unos pocos grados por encima. Los puntos fusión Mettler de SOS, SLS y SInS fueron $44.1,37.9$ y $36.5^{\circ} \mathrm{C}$ respectivamente. Los calores de fusión de los triacilgliceroles estructurados determinados por DSC resultaron del orden de $29-32 \mathrm{cal} / \mathrm{gm}$ frente a $45 \mathrm{cal} / \mathrm{gm}$ del SSS. Se calcularon los calores de fusión también mediante las determinaciones de los puntos de goteo Mettler como mezclas con aceite de soja y mostraron una buena concordancia con los datos DSC.

PALABRAS-CLAVE: Aceite de soja - Calor de fusión - Calorimetría diferencial de barrido - Lípidos estructurales - Punto de goteo Mettler - Resonancia magnética nuclear.

\section{SUMMARY}

Melting properties of some structured lipids native to high stearic acid soybean oil.

A number of structured lipids native to high stearic acid soybean oil were synthesized and their physical properties were determined by pulsed nuclear magnetic resonance (NMR), Mettler dropping point and differential scanning calorimetry (DSC). 1,3 Distearo-2-olein (SOS), 1,3 distearo-2-linolein (SLS) and1,3 distearo-2-linolenin (SInS) were synthesized from pure 1,3 diacylglycerols and the appropriate fatty acid. Pulsed NMR determinations over the temperature range $10-50^{\circ} \mathrm{C}$ showed that the symmetrical triacylglycerols (SUS: where $S=$ stearic, $U=$ oleic, linoleic or linolenic) are high and sharply melting materials, all showing substantial amounts of solids at temperatures up to $33.3^{\circ} \mathrm{C}$, yet are completely melted at only a few degrees higher. Mettler dropping points for SOS, SLS and SInS were 44.1, 37.9 and $36.5^{\circ} \mathrm{C}$ respectively. The heats of fusion for the structured triacylglycerols were determined by DSC and shown to be of the order 29-32 cal/gm compared to $45 \mathrm{cal} / \mathrm{gm}$ for SSS. The heats of fusion were also calculated from Mettler dropping point determinations as admixtures with soybean oil and showed consistent agreement with the DSC data.

KEY-WORDS: Differential scanning calorimetry - Heats of fusion - Mettler dropping point - Nuclear magnetic resonance - Soybean oil - Structured lipids.

\section{INTRODUCTION}

During the past decade a number of structurally modified soybean oils high in saturated acids have been introduced (Lui 1999, List et al. 1996, List et al. 1997). In their natural state, these oils exhibit melting points about $15^{\circ} \mathrm{C}$ lower than hydrogenated oils used in spreads and they lack sufficient solids at temperatures above $10^{\circ} \mathrm{C}$ (i.e. $21.1-33.3^{\circ} \mathrm{C}$ ). This work was undertaken to characterize the physical properties of some structured lipids native to high stearic acid soybean oil.

\section{MATERIAL AND METHODS}

Stearic $(\mathrm{S})$, oleic $(\mathrm{O})$, linoleic $(\mathrm{L})$ and linolenic (Ln) acids were purchased from Nu-Chek-Prep, Elysian, MN and were found $100 \%$ pure after conversion to methyl esters and analysis by gas chromatography. The symmetrical triacylglycerols, SOS, SLS and SInS, were synthesized from 1,3-distearyl glycerol according to Kodali (1987). SOS, SLS and SInS showed purities of $98.4,100$ and $100 \%$ respectively as determined by HPLC (Neff et al. 1994). SOS contained $1.6 \%$ tristearin as an impurity.

The solid fat content (SFC) was determined by pulsed nuclear magnetic resonance spectroscopy according to the official AOCS method (Anon 1989). A Bruker Minispec instrument was used, Toronto, $\mathrm{ON}$. The temperature range studied was from $10-50^{\circ} \mathrm{C}$. Drop melting points were determined according to the official AOCS method and values reported are the means of duplicate determinations (Anon 1989). The agreement between duplicates was equal to or better than the $\pm 1.4^{\circ} \mathrm{C}$ variability reported as acceptable for the method.

Heats of fusion $(\Delta \mathrm{H})$ were determined by differential scanning calorimetry (DSC) according to 
Table I

Physical properties of structured triacylglycerols

\begin{tabular}{|c|c|c|c|c|c|c|c|c|c|c|c|c|}
\hline & & & & & & & & & & & & $\Delta \mathrm{H}$ \\
\hline & & & Solid & Fat & tent $(S$ & $=\mathrm{C}) @$ & Temp., & ${ }^{0} \mathrm{C}^{\mathrm{a}}$ & Melting & Point & $\mathrm{DSC}^{\mathrm{C}}$ & Melting Point \\
\hline Triglyceride & Purity, \% & 10 & 21.1 & 26.7 & 33.3 & 40 & 45 & 50 & Drop Pt., ${ }^{\circ} \mathrm{C}^{b}$ & $\mathrm{DSC},{ }^{\circ} \mathrm{C}$ & $\mathrm{j} / \mathrm{gm}$ & $\mathrm{j} / \mathrm{gm}$ \\
\hline SSS & 100 & 99.6 & 99.5 & 99.4 & 93.3 & 99.0 & 98.3 & 98.1 & 73.5 & 73.3 & 188.3 & 159.1 \\
\hline SOS & 98.4 & 98.1 & 97.5 & 97.0 & 93.1 & 65.0 & 4.1 & 1.4 & 44.1 & 39.2 & 125.1 & 116.0 \\
\hline SLS & 100 & 88.5 & 87.8 & 87.3 & 79.1 & 0.0 & 0.0 & 0.1 & 37.9 & 38.3 & 134.8 & 116.4 \\
\hline SLnS & 100 & 87.9 & 86.6 & 79.4 & 38.8 & 0.3 & 0.0 & 0.0 & 36.5 & 38.3 & 134.4 & 129.8 \\
\hline EEE & 100 & 98.8 & 98.6 & 98.1 & 97.6 & 65.0 & 0.0 & 0.0 & 43.5 & 41.6 & 150.7 & 103.0 \\
\hline SSL & 100 & 88.9 & 88.1 & 87.4 & 86.8 & 60.5 & 0.0 & 0.0 & 42.3 & 31.8 & 138.6 & 133.9 \\
\hline
\end{tabular}

${ }^{a}$ By pulsed NMR, AOCS method Cc 18-80

AOCS method CC 16-60

AOCS method Cj 1-94

the official AOCS method (6). A TA instruments model 2910 DSC was used, New Castle, DE. Melting points by DSC were found to have a standard deviation of $\pm 1.3 \%$ and were within the ranges reported for the methodology. Heats of fusion $(\Delta \mathrm{H})$ were reproducible to within $\pm 5.1 \%$.

\section{RESULTS AND DISCUSSION}

Although pulsed NMR had found widespread use to estimate solid fat in triacylglycerol oils (List et al. 2001), little or no data have been published for pure, individual triacylglycerols. The solid fat contents of the symmetrical triacylglycerols SOS, SLS and SInS are given in Table I along with their drop melting points and heats of fusion. Their solid fat content over $10-50^{\circ} \mathrm{C}$ range shows the interesting functional properties of these triacylglycerols since, at the temperatures used to define the solid fat content of an edible oil, they show high, but sharply melting properties. Triacylglycerols which melt sharply are particularly important components of food oils since they impart a pleasant, cooling sensation in the mouth and, therefore, affect the sensory properties of spreads (Bessler and Orthoefer 1983). At temperatures of $10-33.3^{\circ} \mathrm{C}$ they all contain high amounts of solids (39-93\%) yet are completely melted at $36-44^{\circ} \mathrm{C}$. The completely saturated SSS triglyceride melts at $73.5^{\circ} \mathrm{C}$, while SOS, which contains 1 double bond $/$ molecule, melts at $44.1^{\circ} \mathrm{C}, 2$ double bonds $/$ molecule (SLS) melts at $37.9^{\circ} \mathrm{C}$ and 3 double bonds/molecule (SLnS) melts at $36.5^{\circ} \mathrm{C}$.

Compared to the melting points of fully trisaturated triacylglycerols, including tristearin (SSS), tripalmitin (PPP), trimyristin (MMM) and trilaurin (LaLaLa), the introduction of oleic acid into the two position, forming symmetrical triacylglycerols, lowers the melting point about $30^{\circ} \mathrm{C}$.
For example, SSS melts at $73.5^{\circ} \mathrm{C}$ compared to $44.1^{\circ} \mathrm{C}$ for SOS, tripalmitin melts at $65.5^{\circ} \mathrm{C}$ compared to $35.2^{\circ} \mathrm{C}$ for POP, trimyristin melts at $57^{\circ} \mathrm{C}$ compared to $26.3^{\circ} \mathrm{C}$ for MOM and LaLaLa melts at $46.4^{\circ} \mathrm{C}$ compared to $16.5^{\circ} \mathrm{C}$ for LaOLa (Bailey 1950).

The heat of fusion data (B form) for SSS, SOS and SLS are in agreement with Sato (2001) while the heat of fusion for SInS has not been reported. Heats of fusion were also calculated from Mettler dropping point determinations as admixtures with soybean oil and the results, with the exception of SSS, showed consistent agreement with the DSC data.

\section{ACKNOWLEDGMENTS}

K.R. Steidley conducted the experimental work.

\section{REFERENCES}

Anon. Official and tentative methods of the American Oil Chemists' Society. 1989. Ed: D. Firestone. SFC Cc 18-80, Mettler dropping point Cc 16-60, DSC Cj 1-94. American Oil Chemists' Society, Champaign, IL.

Bailey, A.E. 1950. Melting and solidification of fats. Interscience, New York. Pp. 153,166.

Bessler, T.R. and Orthoefer, F. 1983. Providing lubricity in food fat systems. J. Am. Oil. Chem. Soc. 60:1765-1768.

Kodali, D.R., Atkinson, D., Redgrave, T.G., and Small, D.M. 1987. Structure and polymorphism of 18-carbon fatty acyl triacylglycerols: effect of unsaturation and substitution in the 2-position. J. Lip. Res. 28:403-413.

List, G. R., Mounts, T. L., Orthoefer, F., and Neff, W. E. 1996. Potential margarine oils from genetically modified soybeans. J. Am. Oil Chem. Soc. 73:729-732.

List, G. R., Mounts, T. L., Orthoefer, F., and Neff, W. E. 1997. Effect of interesterification on the structure and physical properties of high-stearic acid soybean oils. J. Am. Oil. Chem. Soc. 74:327-329.

List, G.R., Steidley, K.R., Palmquist, D., and Adlof, R.O. 2001. Solid fat index (SFI) vs. solid fat content (SFC): A comparison of dilatometry and pulsed NMR for solids in hydrogenated soybean oil. In Crystallization and 
Solidification of Lipids. Ed: N. Widlak, R. Hartel and S. Narine. American Oil Chemists' Society, AOCS Press, Champaign, IL. Pp. 146-152.

Lui, K. 1999. Soy oil modifications: Products, applications. Inform 10:868-877.

Neff, W. E., Adlof, R. O., List, G. R., and El-Agaimy, M. 1994. Analysis of vegetable oil triacylglycerols by silver ion high performance liquid chromatography. J. Liq. Chem. 17:3951-3968.
Sato, K. 2001. Molecular aspects in fat polymorphism. In Crystallization and Solidification of Lipids. Ed: N. Widlak, R. Hartel and S. Narine. American Oil Chemists' Society, AOCS Press, Champaign, IL. Pp. 1-17. 